\title{
Case Study as a Research Method for Arabic Language Education
}

\author{
Kisno Umbar ${ }^{1}$, Ubaid Ridlo ${ }^{2}$ \\ \{kisno_umbar18@mhs.uinjkt.ac.id ${ }^{1,} \underline{\text { ubaid.ridlo@uinjkt.ac.id² }}$ \} \\ ${ }^{1,2}$ UIN Syarif Hidayatullah Jakarta, Indonesia
}

\begin{abstract}
Abstrak. The purpose of this study is to answer the minimum use of case studies approach by the Master candidates of Arabic Language Education at State Islamic Universities (PTKIN) in Indonesia. In fact, theoretically, the case study approach is said to be not only able to solve learning problems but it can also provide recommendations for solving Arabic Language Education problems in formal and informal institutions. This research is qualitative research. Data were collected in two ways. Firstly, an open-ended questionnaire distributed to the Master candidates of Arabic Language Education. Secondly, searching the research archives of four campuses, namely UIN Syarif Hidayatullah Jakarta UIN Sunan Kalijaga Yogyakarta, UIN Surabaya, IAIN Tulungagung, IAIN Surakarta, accessed at campus repository page in the period of 2008 2018. This research reveals two main problems. First is from the personal aspects of researchers. The level of the researchers understanding of case studies is superficial. Research using case studies requires considerable time and huge amount of costs. Second is from the aspect of methodological accuracy. There are a number of principle concept mistakes found. For example; in making problem formulations, considering the location and time of research, and a reliable research process.
\end{abstract}

Keywords: case studies, master thesis, the master candidate of Arabic Language Education, Arabic Education

\section{Introduction}

The existence of case studies approach among linguists is still being debated. There are experts who say, that case studies are still classified as pre-experimental research. The objectivity and accuracy of case studies are considered inadequate. Besides, the case study process takes a long time and there are no standard procedures. There is also the difficulty of generalizing it [1].

That means, case studies only have the role of reading the initial phenomena for further experimental research as a follow up action on the field findings. On the other hand, language experts say that case studies are valid and independent scientific research [2]. This means that it can be a research framework up to the verification stage for validity testing.

Among Arabic Education researchers, case studies are one of the valid research methods used in the final project, bachelor thesis, master thesis, as well as a dissertation or publication in national and international journals. Compared with other approaches, case studies are relevant to be applied in evaluating the learning and teaching process of formal and nonformal Arabic institutions. The reason, is that case studies are curative or can be also called retrospective case studies (retrospective case studies) that allow further action of a case under investigation, as it is called treatment. In addition, case studies are also prospective (prospective case study) that is used to read trends [3].

In the context of Arabic Education, case studies can make a major contribution in diagnosing cases or problems that occur in the learning process, cases from the aspect of 
students, educational material, and the process of delivering material and educational facilities. Finally, teachers can take appropriate actions to overcome these problems in order to achieve the learning objectives that have been formulated in the learning design.

\subsection{Research background}

Based on the description above, case studies in the educational world, especially Arabic, have a strategic position. However, research trends that led to the case study approach in this decade are still minimum. The amount of research with a case study approach is not so much based on searches in several repositories or institutional repositories - a service offered by universities to community members for management and dissemination of digital material in the form of research made by institutions and community members, which aim to document and disseminate the results of an institutional campus research [4] - UIN Syarif Hidayatullah Jakarta repository, UIN Maulana Malik Ibrahim Malang repository, UIN Sunan Kalijaga repository, IAIN Tulungagung repository, and IAIN Surakarta repository. The distribution of master thesis research archives using the case study approach is as follows:

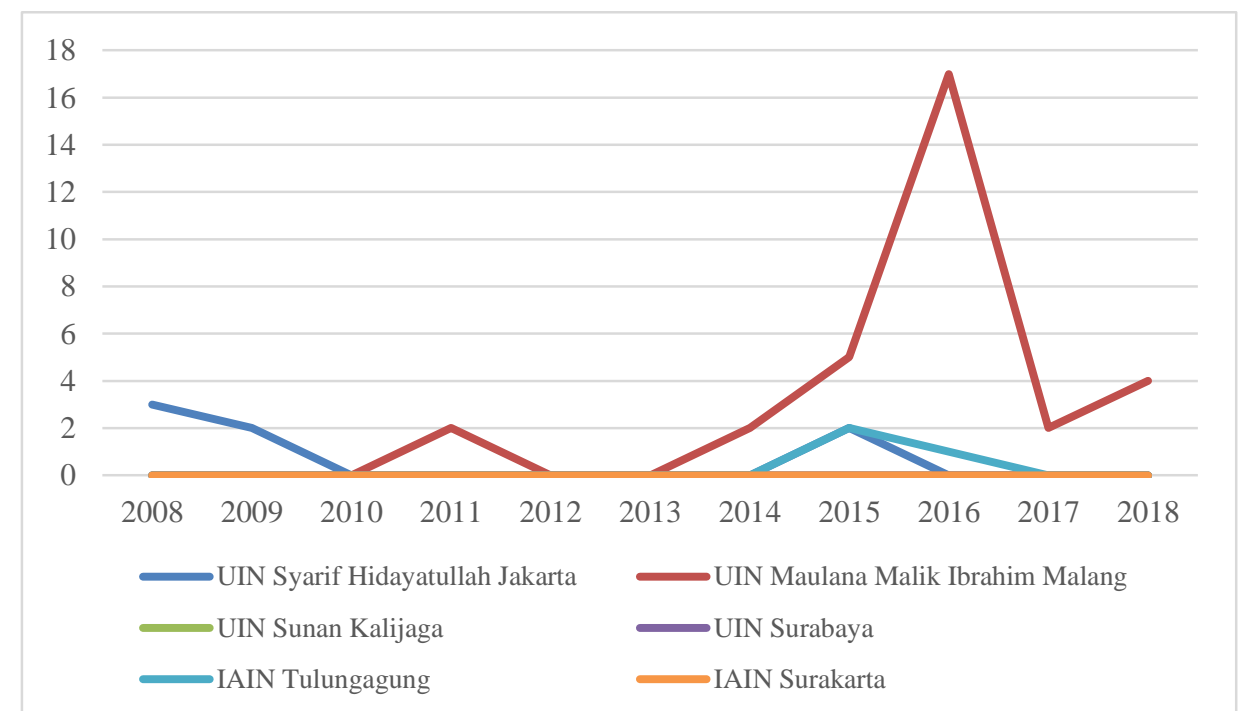

Fig. 1. List of Publications of Arabic Education Thesis Master using case study approach 2008-2018

The data is processed from 6 institutional repository sources that can be accessed openly online

UIN Syarif Hidayatullah Jakarta. From 28 theses research of Arabic Language Education Masters Program (MPBA) Faculty of Tarbiyah and Education Science (FITK) UIN Syarif Hidayatullah Jakarta, there is only one thesis that uses case studies. It was published in 2015, namely Ta'lim wa Ta'alum al-Lughah al -Arabiyah Abra Whatsapp (dirasah halah fi muassasah BISA Depok). Meanwhile at the UIN Jakarta Postgraduate, which has a concentration of Arabic, there were 6 theses using case studies out of 31 theses published from 2008 to 2015.

Arabic language education research with a case study approach began to emerge in 2011, with 2 research titles. In 2012-2013 there were no researchers using this approach, only in 
2014 were there two more studies. Research with a case study approach increased in 2015 with 4 research titles. Then its peak is in 2016. The amount of research with a case study approach was 17 researchs. However, the development of the graph is not stable. In 2017, the amount reduced again to two titles and in 2018 returned to four more titles.

Meanwhile, from researcher investigation through an online repository at UIN Sunan Ampel and UIN Sunan Kalijaga, there have not been found researchers who used a case study approach in the limited time period of the researcher. This does not fully claim that none of the master candidates in the institution have used this approach, but the archives may not have all been digitized and accessed. This also happened at IAIN Surakarta, as well as several other campus institutions.

In contrast to that, in IAIN Tulungagung, Arabic Language Education research with case study approach is available, but not in large numbers. In 2015 there were two titles and in 2016 there were only 1 title.

From these observations, it shows that the distribution of research with a case study approach is still dominated by UIN Maulana Malik Ibrahim Malang. However its development is not stable. If calculated using a percentage formula, it can be seen as follows:

$$
\mathrm{P}=\frac{\mathrm{F}}{\mathrm{N}}
$$

Table 1. List of Publications of Master's Thesis Publications with a Case Study Approach

\begin{tabular}{|l|l|c|c|c|}
\hline No & Institusi & F & N & Persentase \\
\hline 1 & UIN Syarif Hidayatullah Jakarta & 6 & 59 & $10,16 \%$ \\
\hline 2 & UIN Maulana Malik Ibrahim & 32 & 863 & $3,70 \%$ \\
\hline 3 & UIN Sunan Ampel & 0 & 134 & $0 \%$ \\
\hline 4 & UIN Yogyakarta & 0 & 6 & $0 \%$ \\
\hline 5 & IAIN Tulungagung & 3 & 54 & $5,55 \%$ \\
\hline 6 & IAIN Surakarta & 0 & 3 & $0 \%$ \\
\hline \multicolumn{2}{|c|}{ Akumulasi } & 41 & 1.119 & $3,66 \%$ \\
\hline
\end{tabular}

Based on the percentage of each campus, it shows that there is no research trends from several campus institutions that are used as the object. The percentage of case studies in Arabic Language Education research at UIN Syarif Hidayatullah Jakarta only reached 10\%, at UIN Maulana Malik Ibrahim Malang only at 3.7 percent, while at IAIN Tulungagung it reached 5.55\%. Accumulatively, the percentage of case study approach in Arabic research has only reached 3.66 percent. There is no tendency of a research that leads there.

In fact, the case study method in the qualitative research tradition is very calculated. John W. Creswell included it in five major methods in qualitative research, including biography studies (character studies), phenomenology, grounded theory, case studies and ethnography. In fact, Adelman explained that case studies have a strong advantage in reading a reality or case; it can generalize even if it is difficult; represent various points of view and can offer alternative interpretations; and, the results of the case studies can be a feedback for the institution and formative evaluation [5].

\subsection{Problem statement}


Based on the lack of publications in Arabic Language Education master thesis research with a case study approach, researchers formulated two problem questions. First, how do Arabic language education researchers understand how to apply the case study method in their research? This question is used to measure the methodological accuracy used. Second, what are the factors that make Arabic researchers do not really use case studies so much? This question will be seen from the side of the weaknesses of case studies directly related to researchers.

\subsection{Research objective}

Based on the formulation of the problem, the purpose of this research is to find out the understanding of Arabic Language Education researchers on case studies methodologically by referring to how the method is applied to the researchers research. Furthermore, this research is aimed to uncover the reasons of why Arabic researchers do not use case studies so much.

\subsection{Significance of the study}

Theoretically, this research is used to measure the extent of understanding of the master candidates of Arabic Language Education in understanding and implementing case study approach in research accurately and validly. Being a reference for language researchers in the midst of the debate over the use of case studies of a research approach in linguistics. Practically, this research is expected to be a critique of Arabic Language Education research that has not directly touched the aspects of Arabic learning. Moreover, if we look at the advantages of case study approach in describing and answering a problem; opening the insight that the case study approach is still rarely used in Arabic research, most field studies are still focused on experimental studies.

\subsection{Scope of the study}

This research topic is directly related to case studies as an approach in Arabic Language Education research. The researcher reviews how the case study is based on a conceptual framework, the principles that must be followed, and the procedures that must be taken in a case study. Researchers used data collected from online research sourced from six campus repositories that were used as random samples, namely UIN Syarif Hidayatullah Jakarta, UIN Maulana Malik Ibrahim, UIN Sunan Ampel, UIN Sunan Kalijaga, IAIN Tulungagung, and IAIN Surakarta. The researcher's investigation will focus on analyzing errors in the case study approach on a sample determined from 37 studies using case studies from 1.119 master theses on the six campuses. Researcher also distributed questionnaires to Arabic Language Education master candidates to gather their responses in a case study approach.

\section{Literature review}

\subsection{Conceptual framework of case study approach}

Etymologically, case studies are derived from the English translation "a case study" or "case studies". The term "case" in the Oxford Advented Learner's Dictionary is interpreted as 1) "a particular situation or a situation of a particular type, in some cases people have had to wait several weeks for an appointment meaning a certain situation or type of situation for example in one case people must waiting a few weeks for an appointment, 2) "actual state of 
affairs" actual state," 3) "a situation that relates to a particular person or thing" means a situation related to a particular person or thing [6].

Terminologically, according to Johansson, case studies are interpreted as studies that are expected to capture the complexity of a case that has developed in social science [7]. Moreover, a similar definition is also conveyed by Rowley. He says the case study method is the ability to investigate a phenomenon in its context. Employing this approach, he claims that there is no need to replicate phenomena or experiment settings to find out the phenomenon [8]. Fox-Wolfgramm explains the case study quite simply; he calls it a research approach based on qualitative inquiry and collection of unstructured research in social science disciplines that emerged since the 1930s [9].

From some of the boundaries above, there is no significant difference in interpreting case studies and even relatively the same. The keywords of this definition are focused on case words, phenomena, social science, and qualitative. However, to understand in more detail the boundaries of the case studies, the authors agree with the formula proposed by John W. Creswell that case studies are explorations of "bounded systems" or cases (or multiple cases) over time through detailed and in-depth data collection involving many sources of rich contextual information. What is meant by the bounded system by Creswell is the attachment of time and place, and the object being studied can be a program, event, activity, or individual [10].

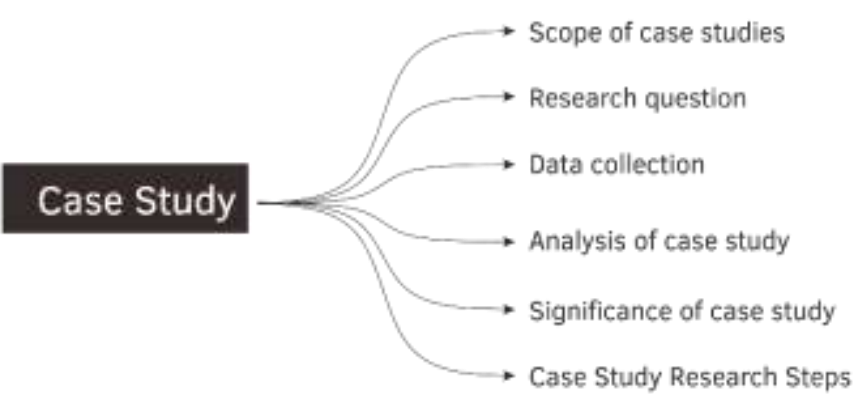

Fig. 2. Conceptual Framework of Case Studies as an Approach to Language Research

Then what cases can be said to be feasible as research objects? The case referred to in the case study can be very simple or very complex. In this case, the researcher must choose one of them, which is more specific. Mudjia underlines the case as something that is classified as "unique" to be studied because it only happens at a certain time and place. Meanwhile, to find out whether or not the object being studied is unique Mudjia cites Stake's opinion which conveys six considerations: 1) the nature of the case; 2) background of the case; 3) the physical setting of a case; 4) the context of the case; 5) other related supporting cases; 6) the informant who mastered the case being studied [11].

\subsection{Case study research questions}

The formulation of research questions in case studies that are commonly asked, because they want to understand phenomena in-depth, even explore and elaborate them, according to Yin is not enough if the case study questions only ask "what, who, where and when" but must use the question "how" and "why ". The "what" question will only lead the researcher to obtain knowledge descriptively, the "who" question will only usher in the involvement of the 
research object, while the question "where" will indicate the location of the case in the event, and the question "when" will answer in relation to time only. Only the use of "how" and "why" questions is considered feasible in case study research. Meanwhile, the use of other types of questions is only as support. The use of how and why questions are considered able to explain the case and provide in-depth answers about the phenomenon being studied [12].

\subsection{Data collection}

Various sources of information relevant to the topic in the case study are needed. The data serves to build a picture and interpret the case in depth. When referring to Yin's view, there are six forms of data collection in a case study. They are, 1) documentation consisting of letters, memorandums, agendas, reports of events, proposals, research results, evaluation results, clippings, articles; 2) archived records consisting of service records, maps, survey data, name lists, personal records such as diaries, calendars, etc.; 3) interviews are usually open-ended type; 4) direct observation; 5) participant observation and 6) physical or cultural equipment that is technological equipment, tools or instruments, artwork [13].

Meanwhile, Creswell displays data collection through a matrix of information sources for its readers. This matrix contains four types of data, which are: 1) observation, including observation as a participant or direct observation; 2) interviews, this can be done with open interviews using notes or with audiotape or structured interview with the formulation of questions that have been derived from the topic of the case being studied; 3) documents, gathering documentary evidence from the cases under study, keeping a diary during conducting research; and 4) audio-visual material, data from videos, photos or e-mails [14].

The data collection method that is presented by the two experts above is not different. The data collection, according to the researcher, is generally the most commonly used in qualitative research. Creswell also clearly states in his book, the method can be used for research on phenomenology, biography, grounded theory, and also ethnography. If mentioned earlier, case studies can also be used using qualitative and quantitative research, questionnaire data collection methods, and statistical data processing can also be said to be part of the case study data collection.

\subsection{Data analysis of case study}

In analyzing the case study data, the Creswell uses six stages. First, the data management process that has been collected. Second, the data reading stage and the researcher create a short message with a small note on each data collected. Third, the description stage, at this stage the researcher must explain the case and its context. Fourth, classification stage, in this phase the researcher must be able to make an effort to categorize and establish a category pattern. Fifth, the interpretation phase, in case studies can use direct interpretation and also make naturalistic generalizations. Sixth, the stage of representing or visualizing, in this section the researcher is expected to be able to present data tables, pictures or illustrations between interpretation and the narrative that is built [15].

On the other hand, Yin recommends four steps of data analysis in case studies, which are: 1) create a pattern, this step is done by using the logic of pattern matching between field facts and alternative predictions. 2) making explanations for analyzing case study data; 3) time series analysis if using an experimental approach in his research; and 4) logical model techniques, the use of logic models as analytic techniques consists of matching events that are observed empirically with theoretically predicted events [16]. 


\subsection{The advantages of case study}

There are several benefits of case studies, among them are as the main means for emic research, which is presenting the views of the subjects studied; case studies can reveal realities similar to what readers read about in real everyday life; case studies can be an effective means of showing the relationship between researchers and interviewees or informants; case studies allow readers to find internal consistency that is not only style consistency and factual consistency but also trustworthiness, case studies provide the "thick description" needed for the assessment of transferability; and case studies are open to the assessment of contexts that contribute to the meaning of phenomena in that context [17].

\subsection{The disadvantages of case study}

Case study as a research approach cannot be separated from the element of weakness. As for some of these weaknesses, such as the first, the case study is often seen as less scientific or pseudo-scientific because the measurement is subjective or cannot be quantified, this criticism also questions the validity of case study research. Second, due to the problem of subjective interpretation in the collection and analysis of case study data, this work is relatively difficult from quantitative research. Third, the problem of generalization, because the scope of research both the issue and the number of people targeted by case studies are very small, the ability of generalization in case studies is low. Fourth, the implementation costs are relatively expensive, and the time required is relatively long. However, it is directly proportional because of the depth of information extracted in the case study. As for the fifth disadvantage, because of the flexibility of the case study design, this allows researchers to shift focus [18].

\subsection{The steps of the case study}

The step of case study research according to Mudjia Rahardjo version can be divided into the following steps: theme selection, reading literature, formulation of focus, data collection, data refinement, data processing, data analysis, data analysis process, theoretical dialogue, triangulation of findings, conclusions of research findings [19].

\section{Methodology}

\subsection{Research Design}

This research is descriptive qualitative research. The researcher employed the first primary data from the book entitled "Qualitative Inquiry and Research Design: Choosing Among Five Tradition" by Creswell, John W and "Case Study Research Design and Methods" by Yin, Robert K, second, archive of master thesis research published on six selected campuses namely UIN Syarif Hidayatullah Jakarta, UIN Maulana Malik Ibrahim Malang, UIN Sunan Ampel, UIN Sunan Kalijaga, IAIN Tulungagung, and IAIN Surakarta in 2008-2018. The choice of the campus was based on the availability of the campus research archive uploaded on institutional repository page. The primary data also sourced from the results of an open digital questionnaire to Arabic language education master candidates in several related universities. Moreover, the secondary data in this study is the views of figures and reference books related to case studies. The researcher utilized descriptive analysis to read the search results for that data. 


\subsection{Instruments}

In this research, there are several research instruments; the first is the researcher himself as the main instrument. It is because, in qualitative research, the researcher can capture the meaning implied behind information and social phenomena encountered in the field. Also, it is because there is no instrument in the form of a test or questionnaire that can capture the whole situation except humans [20]. Second, the master thesis research archives that were recorded from 2008 - 2018. Third, Researcher used in-depth interview instruments to master Arabic language education candidates to get answers directly responding related to the theoretical framework of case studies and their use in research.

\subsection{Sample}

To analyze the appropriateness of using the case study approach, the researcher used a random sampling approach to determine the master thesis to be analyzed for the level of accuracy from its methodological aspects. According to Sugiyono, a simple random sampling technique is a sampling technique from members of the population that is carried out randomly without regard to strata that exist in that population [21].

\section{Data analysis and result}

\subsection{Analysis of methodological appropriateness of case studies in Arabic Language Education}

\subsubsection{The accuracy of the case}

\section{Sampel I}

The research entitled "ta'lim wa ta'alum al-lughah al-arabiyah" abra al-whatsapp (dirasah halah fi muassasah BISA al-islamiyah Depok Indonesia" written by Ana Rizkiya 2017 - UIN Syarif Hidayatullah Jakarta [22].

The study revealed a unique case applied by the BISA foundation in Depok in their way of teaching Arabic. Learning Arabic, which is usually done in classrooms, or outside, is designed to be done online through social media Whatsaap. In fact, social media is usually a place to communicate, spread information, news, videos, and photos. However, the said institution, established in 2013, in the statement of researchers took an alternative by using Whatsapp as a medium for learning and teaching Arabic which is more flexible and can be done anywhere.

In the midst of the rapid technology development as well as online learning media, the use of Whatsap as a learning medium is an interesting case against the idea of just being a communication medium. The case can be said as an actual case by creating a new learning container with no age, space or time restrictions. Interestingly the case is also in the midst of the sluggish development of Arabic Language Education

The object of the case study research above, according to the author, can be said to be very interesting. The research can be said to be still contemporary and relevant to developments in the world today. The narration raised is also interesting. Usually someone only uses social media for communication purposes only. This can be a learning medium that is actually quite effective, because it is not limited by space and time. Therefore, reading the basic pattern of the program becomes important and can later be developed again in various social media. 
Although the case revealed by the author is interesting, the author forgets that the case in the case study has the principle of bounded system, meaning that the research is timelimited. In the study, researchers did not enter a time limit when the study was conducted.

\section{Sampel II}

The research entitled "Asalib at-tafa'ulfi ta'lim al-lughah al-arabiyah dirasah halah fi madrasah tsanawiyah al islamiyah al-hukumiyah al-tsalisah Kediri" written by Alfi Elok Rahmawati 2016 - UIN Maulana Malik Ibrahim Malang [23].

The author in this master thesis examines the communication patterns of Arabic learning with case studies in MTs Negeri 3 Kediri. The reason the author uses case studies is because the focus of the case raised is the interaction patterns between Arabic language teachers and students, and communication among the students. MTs Negeri 3 is one of the best schools in Kediri and the author conveys that students in schools are proficient in Arabic. The author builds his research argument by explaining the benefits of interaction in learning situational relationships.

If you look at the level of interest of a case, then the simple question the researcher poses to the author, is that: what underlies the research to be conducted at MTs Negeri 3 Kediri? Can the research be carried out in other cities? In the city of Malang for example? This shows that the research is not unique. In addition, the case also does not have actual and contemporary elements that can truly be revealed the aspects of its uniqueness.

In this case, the researcher assessed that the writer was trapped in the case of communication between Arabic Language teachers and their students in the class, about how the Arabic learning patterns was, so that the students were proficient in Arabic which could actually be an interesting case. Departing from the author's data, it mentions that the students MTs Negeri 3 Kediri is fluent in Arabic. For example, it is proved by the achievements of MTs Negeri 3 Kediri students who always win Arabic national to international class debates, and various other Arabic language skills.

Even so, the authors hold the principle of bounded systems in case studies by providing a limit of research conducted for two months, namely from May to June to June of 2014-2015 school year.

\section{Sampel III}

Research entitled "Implementasi Multiple Integences dalam Pembelajaran Bahasa Arab (Studi Multi Kasus di SDI al- Munawwar Tulungagung dan MI Al Azhar BandungTulungagung tahun pelajaran 2014-2015" written by Achmad Qodim - 2015 - IAIN Tulungagung [24].

This study originated from the authors' observations on the use of the multiple intelligence approach, especially in the field of Arabic education in private educational institutions, namely SDI al-Munawwar Tulungagung and MI Al-Azhar Bandung Tulungagung, in learning Arabic. The author argued that the application of multiple intelligence is still rarely applied in early schools, even though at the early ages 6-12 is the right time to instill intelligence in children. Starting from verbal linguistic intelligence, mathematical logic, visual spatial, musicalarimatic, interpersonal, intrapersonal, kinesthetic guarantee, naturalist and spiritual extension.

If the measurement is the rarity of applying multiple intelligences, the case is quite interesting and actual to be applied in learning Arabic at the age of 6-12 years. However, the case becomes not interesting because the author does not explicitly explain where schools are applying multiple intelligence. If there are other schools that apply the multiple intelligence 
method, then what are the advantages of applying multiple intelligence in the two schools? Researchers also have not revealed the advantages of using multiple intelligence methods compared to other methods in learning Arabic. Instead, the researcher presents the advantages of the method in the conclusion. Multiple cases raised also did not show any clear distinction between the two, whether the application at SDI al-Munawar was directly proportional to the increase in Arabic language proficiency, nor the application at MI Al-Azhar was not directly proportional to the increase in students' Arabic proficiency.

\subsubsection{Research questions used}

Table 2. Problem questions in Sample I

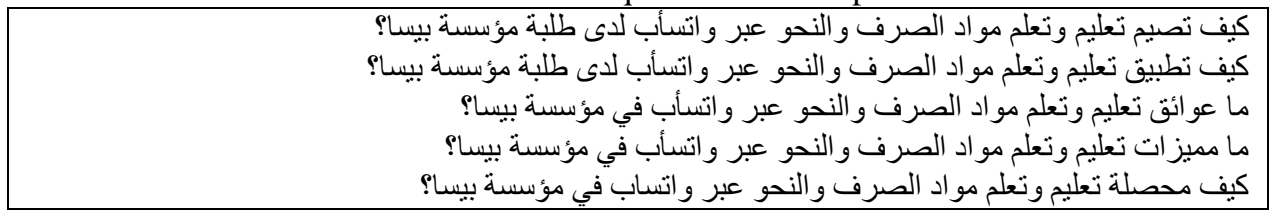

In the study, the authors used the كيف/how question instrument without using the why لماذا/ماذا/ question. The author chose to use helpful questions in what/L questions that can only describe a case [25]. Based on this formulation, the case why the media of whatsap is an alternative to learning is not answered structurally, even though the writer mentions indirectly.

Table 3. Problem questions in Sample II

1. What is the pattern of interaction in the process of learning Arabic in Madrasah Aliyah Negeri 3 Kediri

2. What is the role of teachers and students in Arabic learning interactions in Madrasah Aliyah Negeri 3 Kediri

3. What are the problems and solutions in the interaction patterns in the process of learning Arabic in Madrasah Aliyah Negeri 3 Kediri.

In the formulation of these questions, the authors also only use the question of how to find out patterns of interaction in learning Arabic. Then the author use a help question that can be used to describe the problem, which is what

Table 3. Problem questions in Sample III

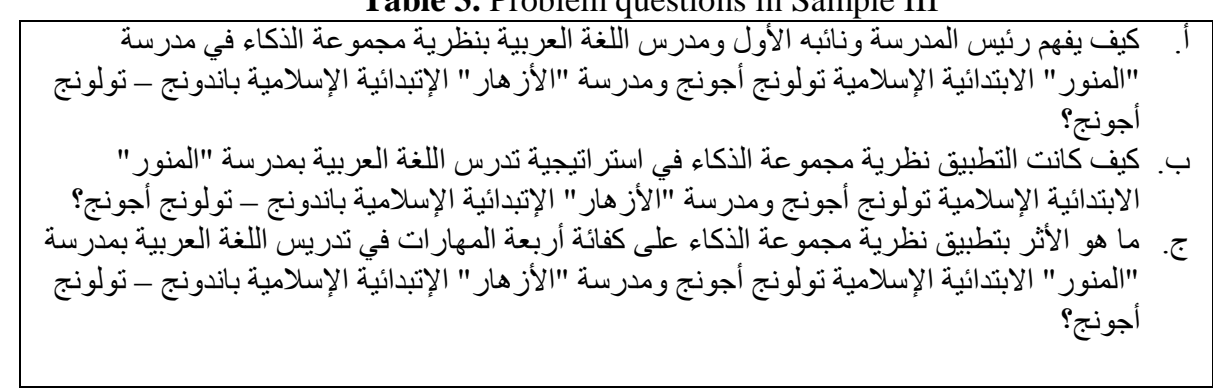

Same case with sample I and sample II, the authors used the question formulation of how, then used the question help of what to describe the application of the multiple intelligence method and to determine its impact on the institution. 


\subsubsection{Data collection strategies}

The three master thesis samples utilized in this study as samples have an element of similarity in data collection. It is because data collection is not much different from other types of qualitative research, which requires observation, in-depth interviews with research objects and organs related to these objects, documentation, and questionnaires if needed.

\subsubsection{Application of data analysis in case studies}

In Sample I, the data was analyzed by the process of analyzing the data in a case study research that was appropriate. Starting from the data selection stage, categorizing the data, doing the patterning, to the data interpretation stage. Moreover, the researcher used data triangulation and auditing methods to test the validity of the results of their research as well.

In Sample II, the researcher divided the analysis process into three parts, namely the pre-field analysis, which is in the form of preliminary observations as secondary data that will be followed up during fieldwork. Then field analysis consists of three stages, which are reducing data, presenting data, and drawing conclusions. Moreover, the researcher also used triangulation to test the truth of the research conducted.

Meanwhile, in sample III, the researcher collected data with a predetermined process, then limits the facts that occur in the field to be analyzed, then presents the facts according to the focus of the study, then the facts are obtained to formulate conclusions and suggestions in the study.

\subsubsection{Strategy of conducting research}

The sample collected did not describe how the research procedure was carried out to prove the openness of the research process. Meanwhile, sample II mentioned the research procedures undertaken by the writer from pre-field research, field research, presenting data and data analysis, interpreting the results of data analysis and formulating conclusions and recommendations, and writing research reports. Then the same steps were taken in sample III, starting from pre-field research, field research, gathering facts and analyzing them then writing research reports.

\subsection{The level of PBA masters students understanding of case studies}

From interviews conducted by the researcher, there were a variety of responses given by PBA master candidates at some of the six universities. Overall, all Arabic language education master candidates are familiar with a case study approach in Arabic research with varying degrees of understanding. It is because the case study approach has been known by them since undergraduate education and deepening in master level education.

Interviewee A, from UIN Syarif Hidayatullah Jakarta, said that conceptually he was sufficient to understand case studies. However, he did not plan to use a case study approach to work on a master's thesis for several reasons - the difficulty in looking for unique cases that deserve to be raised in the study.

Meanwhile, interviewee B, from UIN Maulana Malik Ibrahim Malang, was also familiar with the case study approach. According to him, the approach was familiar on campus, so to find previous research with case studies is quite easy. He planned to use a case study approach in his research. This was based on the profession that he worked as a teacher in one of the favorite schools in the city of Malang. It means that the long-time needed in the case study is not so heavy when he teaches, he can immediately conduct research. 
In contrast to interviewee $\mathrm{C}$ from IAIN Tulungagung, the case study approach in the field of Arabic education is familiar. However, the application is not easy. He also stated that he was not ready to use this approach to do the master's thesis task. According to him, the case study approach is quite complex, starting from the level of the uniqueness of the case to the process of doing it, which needs a lot of time and cost a lot of money.

From the interviewee's information it is known that the constraints in the case study are not from the aspect of understanding the conceptual framework, but rather the factors outside of understanding, which is the field factor, since it requires carefulness to look at the case, requires a lot of time sacrifice and also requires more expensive funding compared to other approaches.

\section{Discussion and recommendation}

\subsection{Discussion}

The objective of this research is to find out the Arabic language researchers' understanding of methodological case studies by referring to how the method is applied to the researcher's research. Furthermore, this research is also aimed at uncovering the reasons for the less number of use of Arabic language researchers in using the case study.

\subsection{Recommendation}

For Arabic education master candidates who will use case studies, they can prepare their research proposals early in semester three so that in semester four, researchers have gone to the field to collect data. For PBA master candidates who have the opportunity to teach formal and non-formal educational institutions, a case study approach can be an option because research can be done by integrating educational activities in the educational institution. If the case study research has significance in the development of Arabic language education widely, researchers can try to find sponsors from the government or non-government to overcome the expensive case study costs.

\subsection{Conclusion}

Based on several numbers of thesis samples selected for analysis, and interviews with several candidates for the masters of Arabic language education, it can be concluded as follows:

First, the thesis shows that masters of Arabic education understand the case study approach in a conceptual framework. However, in the application, several principle errors in methodological still occur. These problems in determining the uniqueness of the case, negligent research is restricted because the case study is a bounded system, the use of research questions that are not appropriate, the formulation of the question that only describes the case but do not answers the case study.

Second, the factors that make many Arabic researchers do not use case studies as the results of interviews is because of several factors which are: the level of interest in a subjective case, the research requires expensive funding, and the sacrifice of a long time, because there is pre-field, research field, and new report writing. 


\subsection{Acknowledgments}

The author would like to thank LPDP (Indonesia Endowment Fund for Education), The Faculty of Educational Sciences of UIN Syarif Hidayatullah Jakarta, for supporting and funding in this research.

\section{References}

[1] Yani Kusmarni, "Studi Kasus (John W.Creswell)," UGM Jurnal Edu UGM Press, 2012.

[2] Muhartoyo, "Introduction to Research Methodologies in Language Studies," Jurnal LINGUA CULTURA Vol.12 No.1 pp. 11-18, 2017.

[3] Endraswara, Suwardi, Metodologi Penelitian Kebudayaan. Yogyakarta: Gadjah Mada University Press, 2012.

[4] S. Ati Suwanto, "Manajemen Layanan Repository Perguruan Tinggi," Lentera Pustaka, Vol. 3 No. 2, pp. 165-176, 2017.

[5] Muhartoyo, "Introduction to Research Methodologies in Language Studies," Jurnal LINGUA CULTURA Vol.12 No.1 pp. 11-18, 2017.

[6] Horby, A S, Oxford Advanced Learner's Dictionary, Ninth Edition. Oxford: Oxford University Press, 2015.

[7] Johansson, Rolf. “Case Study Methodology, ” disampaikan pada internasional konference "Methodologies in Housing Research," Royal Institute of Technology in cooperation with the International Association of People-Environment Studies. Stockholm, September pp. 22-24, 2003.

[8] Rowley, Jennifer. "Using Case Studies in Research." Management Research News, Vol. 25 Iss 1, pp. 16-17, 2002.

[9] Štrach, Pavel dan Everett, Andrě M, "Transforming Research case studies," Qualitative Research in Organizations and Management: An International Journal, Vol. 3 Iss 3, pp. 199 - 214, 2008.

[10] Creswell, John W, Qualitative Inquiry and Research Design: Choosing Among Five Tradition. London: Sage Publications, 1997.

[11] Rahardjo, Mudjia, Studi Kasus dalam Penelitian Kualitatif: Konsep dan Prosedurnya. Malang: UIN Maulana Malik Ibrahim Malang Program Pascasarjana, 2017.

[12] Yin, Robert K, Case Study Research Design and Methods, trird Edition. London: Sage Publications, 2002.

[13] Yin, Robert K, Case Study Research Design and Methods, third Edition. London: Sage Publications, 2002.

[14] Creswell, John W, Qualitative Inquiry and Research Design: Choosing Among Five Tradition. London: Sage Publications, 1997.

[15] Creswell, John W, Qualitative Inquiry and Research Design: Choosing Among Five Tradition. London: Sage Publications, 1997.

[16] Yin, Robert K, Case Study Research Design and Methods. Washington: COSMOS Corporation, 1989.

[17] Mulyana, Dedy, Metodologi penelitian kualitatif: paradigma baru ilmu komunikasi dan ilmu sosial lainnya. Bandung: PT Remaja Rosdakarya, 2013. 
[18] Muh. Fitriyah dan Luthfiyah, Metodologi Penelitian: Penelitian Kualitatif, Tindakan kelas \& Studi Kasus. Sukabumi: Jejak Publisher, 2017.

[19] Rahardjo, Mudjia, Studi Kasus dalam Penelitian Kualitatif: Konsep dan Prosedurnya. Malang: UIN Maulana Malik Ibrahim Malang Program Pascasarjana, 2017.

[20] Lincoln, Yvonna S \& Egon G. Guba, Naturalistic Inquiry. California: Sage, 1985.

[21] Sugiyono, Metode Penelitian. Bandung: CV Alfa Beta, 2001.

[22] Rizkiya, Ana. "Ta'lim wa Ta'allum al-lughah al-arabiyah 'abral Whatsapp (Studi Kasus di lembaga BISA Depok". Tesis Magister Pendidikan Bahasa Arab UIN Syarif Hidayatullah Jakarta, 2017.

[23] Alfi Elok Rahmawati, "Asalib at-tafa'ulfi ta'lim al-lughah al-arabiyah dirasah halah fi madrasah tsanawiyah al islamiyah al-hukumiyah al-tsalisah Kediri," master thesis, UIN Maulana Malik Ibrahim Malang, 2016.

[24] A. Qodim, "Implementasi Multiple Integences dalam Pembelajaran Bahasa Arab (Studi Multi Kasus di SDI al- Munawwar Tulungagung dan MI Al Azhar Bandung-

Tulungagung tahun pelajaran 2014-2015," master thesis, IAIN Tulungagung, 2015.

[25] Yin, Robert K, Case Study Research Design and Methods, trird Edition. London: Sage Publications, 2002. 